\title{
Lipoproteins and Cardiovascular Diseases
}

\author{
Adebowale Saba and Olayinka Oridupa
}

Additional information is available at the end of the chapter

http://dx.doi.org/10.5772/48132

\section{Introduction}

\subsection{What are lipids?}

Lipids consists of a broad group of naturally occurring molecules that include fats, waxes, sterols including cholesterol, fat-soluble vitamins (such as vitamins A, D, E, and K), monoglycerides, diglycerides, triglycerides, phospholipids, and others. Lipids were previously known as sources of energy storage and the building blocks for cell membrane. Lipids are now known to play several key roles in intracellular signalling, membrane trafficking, hormonal regulation, blood clotting (Muller-Roeber and Pical, 2002; Vance and Vance, 2002; Fahy et al., 2009). All lipids may be defined as hydrophobic or amphiphilic small molecules. The amphiphilic nature of some lipids allows them to form structures such as vesicles, liposomes, or membranes in an aqueous environment. Biological lipids originate entirely or in part from two distinct types of biochemical subunits, which are ketoacyl and isoprene groups (Fahy et al., 2009).

Lipids typically do not travel alone in the blood. Instead, it binds to a protein that transports it to its destination in the body. The complex formed by the binding of lipid to protein i.e. lipoprotein, makes lipids water soluble, which enables its transportation in blood. The lipoprotein particle is composed of an outer shell of phospholipids, which renders the particle soluble in water; a core of fats called lipid, including cholesterol and a surface apoprotein (apolipoprotein). Ideally, the lipoprotein aggregates should be described in terms of the different protein components (apolipoprotein) because this determines the overall structures and metabolism of the lipoprotein, and the interactions with receptor molecules in liver and peripheral tissues. The apolipoprotein molecule enables tissues to recognize and take up the lipoprotein particle. However, lipoproteins are classified based on their characteristic density on ultracentrifugation, which has been used to segregate the different lipoprotein classes. Lipoproteins are broadly classified as high density lipoprotein (HDL), low density lipoprotein (LDL), intermediate density lipoprotein (IDL), very low density lipoprotein (VLDL) and chylomicrons (CM). Each of these particles perform 
different functions and can be detrimental (VLDL, IDL, LDL) or beneficial (HDL) to the cardiovascular system.

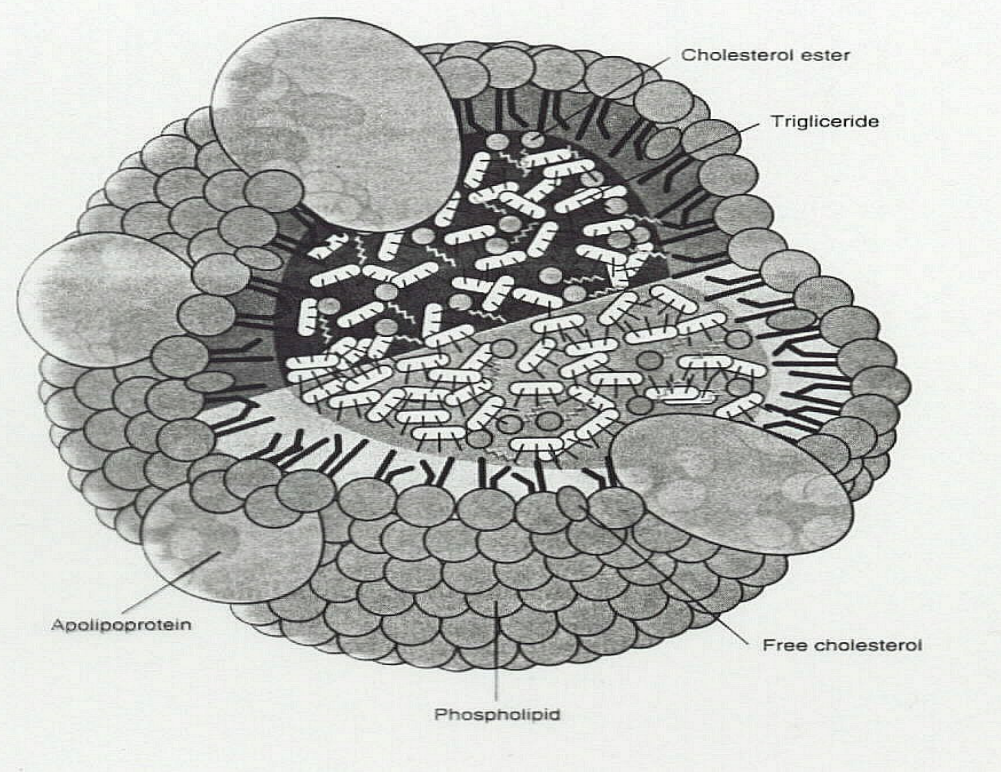

Figure 1. Structure of Lipoprotein available from http://www.campbell.edu

\begin{tabular}{ccccc}
\hline & CM & VLDL & IDL & HDL \\
\hline Density $(\mathrm{g} / \mathrm{ml})$ & $<0.94$ & $0.94-1.006$ & $1.006-1.063$ & $1.063-1.210$ \\
\hline Diameter $(\mathrm{A})$ & $6000-2000$ & 600 & 250 & $70-120$ \\
\hline Total lipid $(\mathrm{wt} \%)^{*}$ & 99 & 91 & 80 & 44 \\
\hline Triacylglycerols & 85 & 55 & 10 & 6 \\
Cholesterol esters & 3 & 18 & 50 & 40 \\
\hline Cholesterol & 2 & 7 & 11 & 7 \\
Phospholipids & 8 & 20 & 29 & 46 \\
\hline
\end{tabular}

*Most of the remaining materials comprise the various apolipoproteins

Table 1. Physical properties and lipid compositions of lipoprotein classes

\subsection{Role of cholesterol in membrane dynamics}

It is relevant to establish the important of cholesterol in the body to be able to relate the various metabolic events associated with cholesterol and its homeostasis. Mammalian cell membranes contain varying proportions of cholesterol depending on organelle and cell type. These levels are tightly controlled by lipid transfer, through both vesicular and protein-bound pathways. With its rigid sterol backbone, cholesterol preferentially locates 
among saturated membrane lipids that have straight, elongated hydrocarbon chains rather than among kinked, unsaturated species. The presence of cholesterol in the membrane increases lateral ordering of lipids, reducing permeability and fluidity and potentially restricting diffusion of membrane proteins. Its distribution is not uniform within a membrane: regions of high cholesterol and corresponding low fluidity are termed lipid rafts. These areas act as platforms for the assembly of signalling complexes within the membrane and have been implicated in the development of numerous disease processes, notably arteriosclerosis and cancer (Di Vizio et al., 2008; Ikonen, 2008).

\section{Cardiovascular disease and risk factors}

Elevated plasma levels of low density lipoprotein (LDL) and low levels of high density lipoprotein (HDL) poses a major risk of development of cardiovascular diseases (Grundy et al., 1999). A dietary intake of saturated fat and a sedentary lifestyle has been associated with about $31 \%$ of coronary heart disease and $11 \%$ of stroke in humans. According to the Framingham Heart Study and other studies (Wilson et al., 1998), the major and independent risk factors for coronary heart disease (CHD) are cigarette smoking of any amount, elevated blood pressure, elevated serum total cholesterol and low-density lipoprotein cholesterol (LDL-C), low serum high-density lipoprotein cholesterol (HDL-C), diabetes mellitus, and advancing age. More recently, a review by Patrick and Uzick (2001) documented new risk factors for CHD which included levels of circulating homocysteine, fibrinogen, C-reactive protein (CRP), endogenous tissue plasminogen-activator, plasminogen-activator inhibitor type I, lipoprotein(a), factor VII and certain infections such as Chlamydia pneumonia. These studies showed that the total risk of an individual is the summation of all major risk factors.

Other factors contributing to the total risk for CHD are categorized as conditional risk factors and predisposing risk factors. The conditional risk factors are associated with increased risk for CHD, although their causative, independent, and quantitative contributions to CHD have not been well documented. The predisposing risk factors are those that worsen the independent risk factors. Two of these risk factors; obesity and physical inactivity, are designated major risk factors by the American Heart Association (AHA) (Fletcher et al., 1996; Eckel, 1997). The adverse effects of obesity are worsened when it is expressed as abdominal obesity, an indicator of insulin resistance. These risk factors apply before clinical manifestation of coronary atherosclerotic diseases. The clinical significance of these risk assessment is to identify high-risk patients who require attention, motivate patients to adhere to risk-reduction therapies and modify the intensity of risk reduction effort required in potential patients (Grundy et al., 1999).

\subsection{Lipoproteins, cholesterol and atherosclerosis}

Cholesterol is a building block of the outer layer of cell membranes. Cholesterol is a waxy steroid of fat that is produced in the liver or intestines. It is used to produce hormones and cell membranes and is transported in the blood plasma of all mammals (Leah, 2009). As an essential structural component of mammalian cell membranes, it is required to establish 
proper membrane permeability and fluidity. In addition, cholesterol is an important component for the manufacture of bile acids, steroid hormones, and vitamin D. Cholesterol is the principal sterol synthesized by animals; however, small quantities can be synthesized in other eukaryotes such as plants and fungi. It is almost completely absent among prokaryotes including bacteria (Pearson et al., 2003).

Owing to its limited solubility in water, cholesterol is transported in blood in lipoproteins. The lipoprotein outer layer is formed of amphiphilic cholesterol and phospholipid molecules, studded with proteins, surrounding a hydrophobic core of triglycerides and cholesterol esters. Lipoproteins are specifically targeted to cells by distinct apolipoproteins on their surface that bind to specific receptors. Low density lipoprotein (LDL) contains the highest level of cholesterol. LDL receptors in peripheral tissues bind LDL, triggering its endocytosis, lysosomal targeting and hydrolysis. When cells have abundant cholesterol, LDL receptor synthesis is inhibited by the sterol regulatory element binding proteins (SREBP) pathway (Wang et al., 1993; Yokoyama et al., 1993; Brown and Goldstein, 2009).

The biosynthesis of cholesterol is intensely regulated in the body with negative feedback of plasma cholesterol levels. The molecular basis of this regulation was set out by Michael Brown and Joseph Goldstein, earning them the Nobel Prize in Physiology and Medicine in 1985 (Leah, 2009). A key irreversible step of cholesterol synthesis is catalyzed by HMG-CoA reductase. Transcription of the HMG gene is controlled by SREBPs, transcription factors that bind sterol regulatory elements. SREBPs are only able to enter the nucleus when cholesterol levels fall. At other times they are tied up in a complex that includes Scap (SREBP-cleavage activating protein), an escort protein with a cholesterol-binding motif that senses cellular cholesterol levels. The SREBP pathway is now implicated in multiple regulatory aspects of lipid formation and metabolism (Brown and Goldstein, 2009).

\subsection{Atherogenicity of lipoprotein sub-fractions}

The first stages of cholesterol build up in the blood vessels (atherosclerosis) occur when LDL particles circulating in the blood penetrate through the inner lining of blood vessels and become trapped in the artery wall. The normal function of LDL is to deliver cholesterol to cells, where it is used in membranes or for the synthesis of steroid hormones. Cells take up cholesterol by receptor-mediated endocytosis. LDL binds to a specific LDL receptor and is internalized in an endocytic vesicle. Receptors are recycled to the cell surface, while hydrolysis in an endolysosome releases cholesterol for use in the cell. The liver removes LDL and other lipoproteins from the circulation by receptor-mediated endocytosis.

Deregulation of cholesterol levels results in the existence of more LDL in the blood than can be taken up by LDL receptors. Excess LDL is oxidized and taken up by macrophages, forming foam cells that can become trapped in the walls of blood vessels along with cells of inflammation (Zioncheck et al., 1991; Young and McEneny, 2001). Fatty streaks, consisting of subendothelial collection of foam cells are initially formed in blood vessels. Small, dense LDL particles are more atherogenic than large, buoyant LDL particles, and oxidation of LDL also increases its atherogenicity. In addition, LDL belongs to the group of lipoproteins that 
contain apolipoprotein (apo) B-100. Some of the particles in this highly heterogeneous group contain other apolipoproteins, such as apo C-II, apo C-III, and apo E. Furthermore, some particles are larger and rich in triglycerides (large VLDL), whereas others are smaller and rich in cholesteryl esters (small VLDL, IDL). It is now known that remnant lipoproteins containing apo C-III are highly atherogenic and may be more specific measures of coronary heart disease (CHD) risk assessment than plasma triglycerides (Carmena et al., 2004).

The end result is the formation of an atherosclerotic plaque which occludes the endothelial lumen and impedes blood flow, leading to myocardial infarction, the major cause of heart attacks and strokes. Although LDL levels correlate with heart attack risk, high density lipoprotein (HDL) has an inverse ratio of risk because HDL particles transport cholesterol to the liver for excretion. Modern cholesterol tests distinguish the LDL/HDL ratio as well as the overall level (Barter et al., 2007). Other sub-fractions of lipoproteins such as chylomicrons, IDL and VLDL may enter the endothelial spaces due to their sizes, thus contribute substantially to development of atherosclerotic plaques. They may also increase prothrombotic factors, triggering cardiovascular diseases (Brunzell et al., 2008).

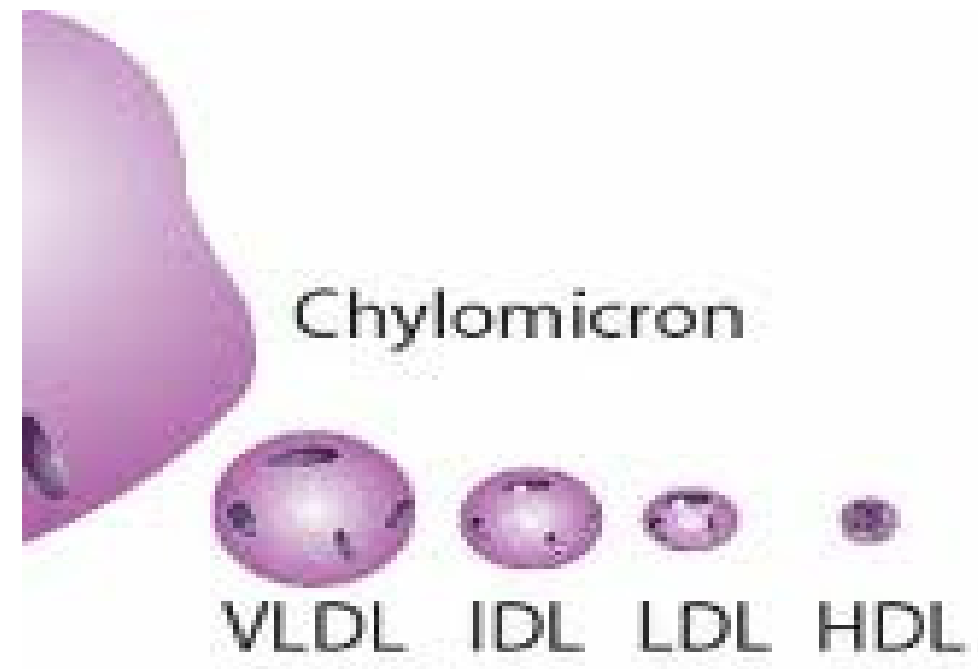

Figure 2. Sizes of Lipoproteins available at http://www.sigmaaldrich.com/european-export.html

Triglyceride-rich lipoproteins comprise a great variety of nascent and metabolically modified lipoprotein particles differing in size, density, and lipid and apolipoprotein composition. Studies have shown an inverse relationship between the size of lipoproteins and their ability to cross the endothelial barrier to enter the arterial intima. Chylomicrons and large VLDLs are probably not capable of entering the arterial wall. On the other hand, small VLDL and IDL can enter the arterial intima. Therefore, certain triglyceride rich lipoproteins are atherogenic, whereas others are not. A large body of evidence suggests that small VLDLs and IDLs are independently associated with atherosclerosis (Carmena et al., 2004). 


\subsection{Apolipoproteins in lipoproteins}

Apolipoproteins are the carrier proteins for lipoproteins and they consist of a single polypeptide chain often with relatively little tertiary structure. They are required to solubilise the non-polar lipids in the circulation and in some instances to recognise specific receptors. They are classified as Apo A1, A2, A4, A5, B48, B100, C1, C2, C3, D, E, H, J, L, M and Apo (a). Most apolipoproteins are synthesised by the liver and intestine.

\begin{tabular}{|c|c|c|c|}
\hline Apolipoprotein & Molecular weight & Lipoprotein & Function \\
\hline Apo AI & 29,100 & HDL & $\begin{array}{l}\text { Lecithin: cholesterol } \\
\text { acyltransferase (LCAT) activation. } \\
\text { Main structural protein. Binds } \\
\text { ABCA1 on macrophages }\end{array}$ \\
\hline Apo AII & 17,400 & HDL & Enhances hepatic lipase activity \\
\hline Apo AIII & 46,000 & $\mathrm{CM}$ & \\
\hline Apo AIV & 46,000 & HDL, CM & Inhibits food intake in CNS \\
\hline Apo AV & 39,000 & HDL & Enhances triacylglycerol uptake \\
\hline Apo B48 & 241,000 & $\mathrm{CM}$ & $\begin{array}{l}\text { Derived from Apo B100 gene by } \\
\text { RNA editing, lacks the LDL } \\
\text { receptor binding site }\end{array}$ \\
\hline Apo B100 & 512,000 & LDL, IDL, VLDL & Binds to LDL receptor \\
\hline Apo CI & 7,600 & VLDL, CM & Activates LCAT \\
\hline Apo CII & 8,900 & VLDL, CM & Activates lipoprotein lipase \\
\hline Apo CIII & 8,750 & VLDL, CM & Inhibits lipoprotein lipase \\
\hline Apo D & 33,000 & HDL & $\begin{array}{l}\text { Closely associated with LCAT, } \\
\text { progesterone binding }\end{array}$ \\
\hline Apo E & 34,000 & HDL & $\begin{array}{l}\text { At least } 3 \text { forms. Binds to LDL } \\
\text { receptor }\end{array}$ \\
\hline Apo(a) & $300,000-800,000$ & LDL, Lp(a) & $\begin{array}{l}\text { Linked by disulfide bonds to apo } \\
\text { B100 and similar to plasminogen, } \\
\text { associated with premature } \\
\text { coronary artery disease and stroke }\end{array}$ \\
\hline Apo $\mathrm{H}$ & 50,000 & Chylomicrons & $\begin{array}{l}\text { Involved with triacylglycerol } \\
\text { metabolism }\end{array}$ \\
\hline Apo M & & HDL & $\begin{array}{l}\text { Transports sphingosine-1- } \\
\text { phosphate }\end{array}$ \\
\hline
\end{tabular}

Table 2. Classes of apolipoproteins, their molecular weight and functions 


\subsubsection{Apolipoprotein A}

Apo A are subdivided into apo AI, AII, AIII, AIV and AV. Apo AI and AII are the major apolipoproteins in the HDL particle. HDL is primarily saddled with the responsibility of removing excess cholesterol from peripheral tissues and delivering it to the liver for excretion in bile as bile acids in a process known as reverse cholesterol transport. Apo AI is synthesised mainly by the liver and also by the intestine. The protein consists of 243 amino acids arranged as eight $\alpha$-helical segments of 22 amino acids which have 11 -mer repeats, no disulfide bonds or glycosylations. The helices are believed to be amphipathic in nature with both hydrophobic and hydrophilic faces. This nature enhances its interaction with the lipid and aqueous phases. Apo AII on the other hand is found as a twin chain of 77 amino acids each, linked by disulfide bonds. It enhances the activity of hepatic lipase, thus increasing lipoprotein metabolism. Apo III is found in chylomicrons.

\subsubsection{Apolipoprotein E}

Three isoforms of this apolipoprotein exist and they are all synthesised mainly by the liver and also by several tissues such as arterial wall, brain and adipose tissue. They are important for homeostasis of lipid and lipoproteins in blood circulation as well as their metabolism in these tissues. Apo $\mathrm{E}$ is required for the clearance of VLDL remnant (IDL) from circulation in the liver. Other suggestions on its involvement with immune response and inflammation have also been put forward.

\subsubsection{Apolipoprotein B}

Two types of apolipoprotein B are synthesised from the intestine and liver as apo B100 which has the full length of 4536 amino acid residues and a truncated form with $48 \%$ of the full length known as apo B48. These proteins which are synthesised on ribosomes, an organelle located on the surface of rough endoplasmic reticulum are translocated through the reticular membrane into the lumen of endoplasmic reticulum. Assembly of VLDL occurs here by accretion of lipids to the core of apo B particle. This occurs in three distinct stages as the apo B grows bigger, forming the pre-VLDL to VLDL 2 which eventually grows to become the triacylglycerol-rich VLDL 1 or chylomicrons, the most energy dense substances in the body. VLDL 2 is a triacylglycerol-poor version of VLDL and its assembly occurs in golgi bodies. This is transported to basolateral membrane of the intestinal cells where final assembly of VLDL 1 or chylomicrons occur and these are secreted into the lamina propria of the intestinal cells by reverse exocytosis.

Apo B100 and B48 are large and water-insoluble, and are the only non-exchangeable apolipoproteins. They are major components of chylomicrons and VLDL, and usually remain with their lipid aggregates throughout their passage in plasma and several metabolic changes occurring during their circulation in plasma. Chylomicrons are usually transported through the intestinal lymphatic system and flow into blood circulation via the left subclavian vein. As apo B carries the VLDL or chylomicrons through the blood stream, their 
triacylglycerol content are removed by peripheral tissues via enzymatic activity of lipoprotein lipase, located in the endothelial wall. This makes free fatty acids available for energy production in muscle and some are stored in adipose tissue. Apo B48 remains with the remnant of the lipoprotein particle, along with dietary cholesterol and apo E. the lipoprotein remnant is eventually cleared from circulation in the liver by an apo E dependent receptor-mediated reaction.

ApoB-100 is one of the largest monomeric proteins known and it is the major apolipoprotein component common to the atherogenic lipoproteins [VLDL, LDL, IDL and Lp(a)] (Boerwinkle et al., 1992; Carmena et al., 2004). Apo B100 differs from apo B48 by the presence of LDL receptor site on the apo B100 molecule. Apo B-100 is encoded for by the Apo B gene and mutations in this gene cause familial hypercholesterolemia, an autosomal hereditary metabolic disorder. The level of apo B-100 is a stronger predictor of risk than LDL in humans. Apo B-100 is speculated to mediate delivery of the cholesterol content of lipoproteins to cells via an unknown mechanism. It is well established that Apo B-100 is associated with atherogenic lipoproteins, thus the number of Apo B-100 can be used to determine the risk of atherosclerosis and CHD in individuals. Apo B-100/apo A-I ratio are strongly and positively related to increased risk of fatal myocardial infarction. Apolipoprotein A-I (apo A-I) is the major apolipoprotein in the HDL structure. The Apo B100/apo A-I ratio is especially valuable in patients with normal or low LDL concentrations, a frequent observation in type 2 diabetes mellitus which may present with hypertriglyceridemia and hyper-apo B concentrations (Carmena et al., 2004).

\subsubsection{Apolipoprotein C}

Apolipoprotein $\mathrm{C}$ is subdivided into three and each has its own distinct function. Apo $\mathrm{CI}$ is involved with activation of Lecithin: cholesterol acyltransferase (LCAT) along with apo AI. This enzyme converts free cholesterol into cholesterol ester, which enhances the incorporation of cholesterol into the lipid core of a lipoprotein particle, particularly in assembly of HDL particle. The enzyme is mainly bound to HDL and LDL in plasma. Apo $\mathrm{CII}$ and CIII have antagonistic activity to each other which are required in regulation of lipoprotein lipase activity. Apo CII is required for activation of lipoprotein lipase, while CIII inhibits lipoprotein lipase activity. Apo CII is believed to open a lid-like region of the enzyme which allows the active site to hydrolyse the fatty acid ester bonds of triacylglycerols. In addition to inhibition of lipoprotein lipase, apo CIII also inhibits the binding of lipoproteins to receptors at the cell surface, thereby decreasing hydrolysis of triacylglycerols. High levels of apo CIII have been associated with elevated serum levels of triacylglycerols (hypertriglyceridemia).

\subsubsection{Transfer of apolipoproteins in lipoprotein homeostasis}

Lipids enter blood circulation bound to apolipoproteins as chylomicrons or VLDL which as secreted into the blood stream from the intestines. Chylomicrons or VLDL consist mainly of apo B100 and B48, but also consist of some apo AI, along with other apolipoprotein which 
will be discussed. These lipoproteins carry triacylglycerol-rich cholesterols to the peripheral tissues to provide sources of energy and for storage, while HDL carries excess cholesterol from peripheral tissue to the liver for excretion in bile acids. Immediately chylomicrons enter blood circulation, an exchange of apolipoproteins occurs between chylomicrons and HDL. The apo AI content of chylomicrons is exchanged for the apo $\mathrm{C}$ and $\mathrm{E}$ content of HDL. Apo $\mathrm{C}$ content is required for activation and inhibition of lipoprotein lipase which hydrolyses the triacylglycerol content of chylomicrons and VLDL, while apo E is needed for the receptor mediated clearance from circulation. Circulation of VLDL and chylomicrons in the blood stream exposes the particles to enzymatic release of triacylglycerols from the lipoprotein core and excess cholesterol is removed from cells. The triacylglycerol- poor and cholesterol rich LDL remnant produced is potentially toxic to the body and needed to be safely cleared from blood circulation. The main concern for this lipoprotein is its toxic effect on the cardiovascular system. The liver scavenges and disposes chylomicrons remnant more effectively than the LDL particles, a mechanism put in place by the body to get rid of the more atherogenic particle of the two; chylomicrons remnant. LDL particles are mostly removed by other mechanisms involving HDL.

\subsubsection{Apolipoprotein(a)}

Apolipoprotein(a) itself is a large glycoprotein that exhibits size heterogeneity among individuals with isoforms that range between $180-700 \mathrm{kDa}$ in size. Apo(a) genotypes were determined using a newly developed pulsed-field gel electrophoresis method which distinguished 19 different genotypes at the apo(a) locus. The apo(a) gene itself was found to account for virtually all the genetic variability in plasma Lp(a) levels (Boerwinkle et al., 1992). The apo(a) cDNA contains multiple tandem copies of a sequence that encodes a cysteine-rich protein motif called a kringle. The particular repeated kringle in apo(a) is designated kringle 4 because it closely resembles the fourth kringle in plasminogen, with the protease domain of apo(a) containing $88 \%$ amino-acid identity to plasminogen. McLean et al. (1992) proposed that the apo(a) isoforms are of different sizes because of variations in the numbers of kringle 4-encoding repeats in the apo(a) gene. The molecular mass of apo(a) protein varies from $187 \mathrm{kDa}$ for an apo(a) that contains 12 kringle 4 domains, to $662 \mathrm{kDa}$ for an apo(a) that contains 50 kringle 4 domains (Carmena et al., 2004).

\subsection{Lipoprotein A [Lp(a)]}

Lipoprotein $[\mathrm{Lp}(\mathrm{a})]$ is a variant of LDL with an additional apolipoprotein in the structure. $\mathrm{Lp}(\mathrm{a})$ is essentially an LDL particle with a large glycoprotein, apolipoprotein (a) [apo(a)] attached to it (McLean et al., 1987; Loscalzo et al., 1990; Boerwinkle et al., 1992; Palabrica et al., 1995). Lp(a) resembles low density lipoprotein (LDL) in lipid composition, but it is distinguished by the presence of apo(a) which is bound by a disulfide linkage to apolipoprotein B-100, a ligand in the LDL molecule by which LDL binds to its receptor. Lp(a) levels has been demonstrated to have a clear association with development of atherosclerosis and other cardiovascular diseases (Zenker et al., 1986; Danesh et al., 2000; Berglund and Anuurad, 2008; Danik et al., 2008). The postulated atherogenicity of Lp(a) is 
probably due to the presence of apo(a) component of the Lp(a) molecule. A study showed that the removal of apo(a) from Lp(a) particles result in a lipoprotein with greatly enhanced affinity for the LDL receptor (Armstrong et al., 1985).

\subsubsection{Synthesis of lipoprotein(a)}

Apo(a) is expressed by liver cells (hepatocytes), and the assembly of apo(a) and LDL particles seems to take place at the outer hepatocyte surface. The half-life of Lp(a) in the circulation is about 3 to 4 days (Rader et al., 1993) and this particle varies in blood concentration from one individual to another from $<0.2->200 \mathrm{mg} / \mathrm{dL}$. Ethnicity is a factor, with those of Asian and African origin averaging the highest concentrations. Within ethnic groups, individual elevation of $\mathrm{Lp}(\mathrm{a})$ is directly associated with increased risk of cardiovascular diseases (Sandholzer et al., 1991; Chien et al., 2008). Lp(a) is usually unaffected by factors like age, blood pressure, and total cholesterol.

\subsubsection{Similarity between lipoprotein(a) and plasminogen}

The structure of $\mathrm{Lp}(\mathrm{a})$ is similar to plasminogen, a naturally occurring glycoprotein that participates in dissolving of clots that form in the bloodstream, and tissue plasminogen activator (tPA). Lp(a) competes with plasminogen for its binding site, leading to reduced fibrinolysis (Loscalzo et al., 1990; Palabrica et al., 1995). Also because Lp(a) stimulates secretion of PAI-1 it leads to thrombogenesis. In addition, because of LDL cholesterol content, Lp(a) contributes to atherosclerosis (Schreiner et al., 1993; Sotiriou et al., 2006) and ultimately a cardiovascular risk factor (Berglund and Ramakrishnan, 2004).

\subsubsection{Correlation between apolipoprotein size and $L p(a)$ concentration}

There is a general inverse correlation between the size of the apo(a) isoform and the Lp(a) plasma concentration (Bowden et al., 1994; Kraft et al., 1996) which is caused by a variable rate of degradation before the apo(a) protein has matured for Lp(a) assembly (White et al., 1994). The plasma concentration of $\mathrm{Lp}(\mathrm{a})$ is unaffected by many physiological, pharmacological, and environmental factors that affect the levels of other plasma lipoproteins (Albers et al., 1977). A genetic determination of plasma Lp(a) levels was strongly suggested due to this lack of environmental and physiological influences. Consistent with this formulation, early genetic studies suggested that the presence of Lp(a) in plasma was inherited as a single autosomal dominant trait (Berg and Mohr, 1963; Iselius et al., 1981), with an estimated heritability level ranging from 0.75 to 0.98 (Boerwinkle et al., 1992).

Plasma Lp(a) concentrations vary 1000-fold between individuals and represent a continuous quantitative genetic trait with a skewed distribution in Caucasian populations (Utermann, 1989). A study was conducted by Lackner et al. (1991) in which the apo(a) gene of members of 12 Caucasian families were segregated. It was found that within a given family, sibling pairs with identical apo(a) genotypes tended to have very similar plasma Lp(a) levels (Lackner et al., 1991). However, individuals with the same apo(a) genotypes who were members of different families often had significantly different plasma concentrations of 
Lp(a). Taken together, these observations suggest that the apo(a) gene is the major determinant of plasma Lp(a) levels and that cis-acting DNA sequences at or near the apo(a) locus, other than the number of kringle 4 repeats, contribute importantly to plasma Lp(a) concentrations (Boerwinkle et al., 1992). Variation in the hypervariable apo(a) gene on chromosome 6q2.6-q2.7 and interaction of apo(a) alleles with defective LDL-receptor genes explain a large fraction of the variability of plasma Lp(a) concentrations (Utermann, 1989).

Furthermore, the size of the apo(a) glycoprotein varies in individuals and this size is inversely correlated with the plasma level of $\mathrm{Lp}(\mathrm{a})$. The reason for the inverse correlation between the size of the apo(a) gene and level of plasma Lp(a) is not known, but a variation of length within the kringle 4-encoding region of the apo(a) gene may account for a greater proportion of the inter-individual variation in plasma $L p(a)$ concentrations. Also, the number of kringle 4 repeats in the gene may not have a direct effect on plasma $\operatorname{Lp}(\mathrm{a})$ concentration (Boerwinkle et al., 1992; Brunner et al., 1996). A study conducted on apo(a) gene of mamorset monkeys showed a plasma $\mathrm{Lp}(\mathrm{a})$ concentration of a very wide range of over a 100-fold, but only one apo(a) isoform (Guo et al., 1991). This may be explained by the differences in the composition of kringle 4 sequence of apo(a) genes in which individuals may have same sizes of apo(a) alleles but different plasma Lp(a) concentrations. The frequency of recombination activity in this locus may be responsible for the variation in their kringle 4 composition and number which may have marked effect on synthesis and /or degradation of Lp(a) (Boerwinkle et al., 1992).

\subsection{Role of oxidation in atherogenesis}

Oxidative stress, especially LDL oxidation has been suggested for almost three decades as the most probable aetiology of atherosclerosis (Steinbrecher et al., 1984). Markers of LDL oxidation in plasma, particularly circulating oxidized LDL and auto-antibodies against oxidized LDL, could be used to assess the development of atherosclerosis in patients (Carmena et al., 2004). Circulating oxidized LDL is additive to the global risk score based on age, sex, total and HDL cholesterol, diabetes mellitus, hypertension, and smoking as a useful marker for identifying persons at risk for CAD (Holvoet et al., 2001; Toshima et al., 2000).

A study has associated circulating oxidized LDL with both subclinical atherosclerosis (clinically silent ultrasound assessed atherosclerotic changes in the carotid and femoral arteries) and inflammatory variables (C-reactive protein and the inflammatory cytokines interleukin- 6 and tumor necrosis factor- $\alpha$ ). This conclusion supports the concept that oxidatively modified LDL may play a major role in development of atherosclerosis (Hulthe and Fagerberg, 2002). It has been proposed that, because of the antigenic properties of oxidized LDL, the anti-oxidized LDL antibody titer could represent a useful index of in vivo LDL oxidation. Autoantibodies against oxidized LDL have been reported to be associated with atherosclerosis, but existing reports are still conflicting. Some studies have reported a positive relationship between autoantibodies against oxidized LDL and CHD (Sherer et al., 2001) whereas another did not (Leinonen et al., 1998). There is a strong cross-reactivity between autoantibodies against oxidized LDL and anticardiolipin antibodies, which have been positively associated with CHD (Erkkila et al., 2000). 


\subsection{Relationship between insulin resistance, diabetes, and small, dense LDL}

Cardiovascular heart disease risk is usually significantly increased when elevated levels of small, dense LDL accompanied by hypertriglyceridemia, reduced HDL-cholesterol levels, abdominal obesity, and insulin resistance. Results from the Que'bec Cardiovascular Study have indicated that persons displaying elevated plasma concentrations of insulin and apo B together with small, dense LDL particles showed a remarkable increase in CHD risk (Lamarche et al., 1999).

Sensitivity to insulin in diabetic and non-diabetic individuals was assessed using nuclear magnetic resonance (NMR) spectroscopy. Insulin resistance had profound effects on lipoprotein size and an increase in serum triglycerides. The lipid profile revealed a 2- to 3fold increase in concentrations of large VLDL particles with no change in medium or small VLDL, increase in overall LDL particle concentration with more small LDL particle size and reduced large LDL. In type 2 diabetes, these alterations could be attributed primarily to the underlying insulin resistance. These changes in the NMR lipoprotein subclass profile predictably increased the risk of cardiovascular disease but were not fully apparent in the conventional lipid profile (Garvey et al., 2003). The Diabetes Atherosclerosis Intervention Study (DAIS) (Vakkilainen et al., 2003) showed that lipid-modifying treatment decreased the angiographic progression of coronary atherosclerosis in subjects with type 2 diabetes. This effect was related in part to the correction of lipoprotein abnormalities. Compared with placebo, fenofibrate treatment significantly increased LDL particle size and HDL cholesterol and decreased plasma total cholesterol, LDL cholesterol, and triglyceride concentrations. The final LDL particle size was inversely correlated with the increase in percentage diameter stenosis (Vakkilainen et al., 2003).

The Pittsburgh Epidemiology of Diabetes Complications Study on whether NMR lipoprotein spectroscopy improves the prediction of coronary artery disease (CAD) in patients with childhood-onset type 1 diabetes, independently of conventional lipid and other risk factors showed that both lipid mass and particle concentrations (NMR spectroscopy) of all VLDL subclasses, small LDL, medium LDL, and medium HDL were increased in CAD cases compared with controls, whereas large HDL was decreased. Mean LDL and HDL particle sizes were also less in CAD cases (Soedamah-Muthu et al., 2003; Carmena et al., 2004).

\subsection{Dyslipoproteinaemia}

Dyslipoproteinaemia is a term broadly used for derangement in lipid and lipoprotein metabolism, which may either be hyperlipoproteinaemia or hypolipoproteinaemia. Dyslipoproteinaemias are generally classified as familial (primary) or acquired (secondary). This chapter discusses hyperlipoproteinaemia with its close relevance to development of cardiovascular diseases. Primary hyperlipoproteinaemias are of genetic origin and may be due to a mutation in a receptor protein which presents as inborn errors of lipid metabolism, and includes common hypercholesterolemia, combined familiar hyperlipidemia, familiar 
hypercholesterolemia, familiar hypertriglyceridemia, VLDL remnants hyperlipidemia and primary chylomicronaemia (Garmendia, 2003). Primary hyperlipoproteinaemia was first classified by Fredrickson and Lees (1965) and this classification was adopted by World Health Organization (WHO). They divided primary hyperlipoproteinaemias into four types and details are show in Table 3 below.

The secondary hyperlipoproteinemias also mimic primary types and may present with similar symptoms. Secondary dyslipoproteinaemias are usually due to other underlying causes that lead to alterations in plasma lipid and lipoprotein metabolism, including hypothyroidism, diabetes mellitus, nephrotic syndrome, chronic biliary obstruction, renal insufficiency. Some drugs modify lipid metabolism and these include alcohol, betaadrenergic blockers, diuretics, progestagens, corticosteroids (Garmendia, 2003). Treatment of the underlying cause or discontinuation of offending drug may resolve the dyslipoproteinaemia. Lipid and lipoprotein abnormalities are common observations and are regarded as modifiable risk factors for development of cardiovascular diseases.

\begin{tabular}{|c|c|c|c|c|c|}
\hline $\begin{array}{l}\text { Hyperlipo- } \\
\text { proteinaemia }\end{array}$ & Sub-type & Classification & Defect & $\begin{array}{l}\text { Lipoprotein } \\
\text { increased }\end{array}$ & Treatment \\
\hline \multirow[t]{2}{*}{ Type I } & a, c & $\begin{array}{l}\text { Familial } \\
\text { hyperchylo- } \\
\text { micronemia }\end{array}$ & $\begin{array}{l}\downarrow \text { Lipoprotein } \\
\text { lipase (LpL) }\end{array}$ & $\begin{array}{l}\text { Chylomicron } \\
\text { S }\end{array}$ & \multirow[t]{2}{*}{$\begin{array}{l}\text { Diet } \\
\text { control }\end{array}$} \\
\hline & $\mathrm{b}$ & $\begin{array}{l}\text { apoprotein CII } \\
\text { deficiency }\end{array}$ & $\begin{array}{l}\text { Altered Apo } \\
\text { CII }\end{array}$ & & \\
\hline \multirow[t]{2}{*}{ Type II } & $\mathrm{a}$ & $\begin{array}{l}\text { Familial } \\
\text { hypercholesterolem } \\
\text { ia }\end{array}$ & $\begin{array}{l}\text { LDL receptor } \\
\text { deficiency }\end{array}$ & LDL & $\begin{array}{l}\text { Bile acid } \\
\text { sequestrant } \\
\text { s, } \\
\text { statins,niac } \\
\text { in }\end{array}$ \\
\hline & $\mathrm{b}$ & $\begin{array}{l}\text { Familial combined } \\
\text { hyperlipidemia }\end{array}$ & $\begin{array}{l}\downarrow \mathrm{LDL} \\
\text { receptor or } \\
\text { and } \uparrow \mathrm{Apo} \mathrm{B}\end{array}$ & $\begin{array}{l}\text { LDL and } \\
\text { VLDL }\end{array}$ & $\begin{array}{l}\text { Statins, } \\
\text { niacin,fibra } \\
\text { te }\end{array}$ \\
\hline Type III & & $\begin{array}{l}\text { Familial } \\
\text { dysbetalipo- } \\
\text { proteinaemia }\end{array}$ & $\begin{array}{l}\text { Apo E2 } \\
\text { synthesis }\end{array}$ & IDL & $\begin{array}{l}\text { Fibrate, } \\
\text { statins }\end{array}$ \\
\hline Type IV & & $\begin{array}{l}\text { Familial } \\
\text { hypertriglyce- } \\
\text { ridaemia }\end{array}$ & $\begin{array}{l}\uparrow V L D L \text { and } \\
\downarrow \text { LpL }\end{array}$ & VLDL & $\begin{array}{l}\text { Fibrate, } \\
\text { niacin, } \\
\text { statin }\end{array}$ \\
\hline Type V & & & $\begin{array}{l}\uparrow \text { VLDL and } \\
\downarrow \text { LpL }\end{array}$ & $\begin{array}{l}\text { VLDL and } \\
\text { chylomicrons }\end{array}$ & $\begin{array}{l}\text { Niacin, } \\
\text { fibrate }\end{array}$ \\
\hline
\end{tabular}

Adapted from Fredrickson classification of hyperdyslipoproteinaemia (Fredrickson and Lees, 1965).

Table 3. 


\subsection{Theories of atherogenesis}

Arteries are blood vessels that carry oxygenated blood from the heart to all tissues of the body. The arterial wall is composed of three layers, namely the intima (inner lining), media and adventitia. A single layer of endothelial cells line the inner surface of the intima, forming a barrier to blood cells and plasma flowing within the blood vessel. Atherosclerosis is characterized by lesions in the intima of arteries, seen as raised fibrous plagues ranging in colour from pearly gray to yellowish gray. The cellular components of the plaque include a cell similar to the adjacent endothelial cell, macrophages, fibrinogen from which fibrin is formed and white blood cells intersparsed between dense connective tissue which consist majorly of collagen fibers. The cells within and around the plaque are usually lipid ladened. Atherosclerosis poses a high risk not just because it can close up an artery, slowing down or entirely restricting blood flow, but may also lead to thrombus formation. A thrombus is a complex aggregation of platelets, red and white blood cells in a fibrin network. Several theories have emanated, suggesting the actual pathogenesis of atherosclerosis.

Schoenhagen (2006) documented the different theories that have been postulated in the course of history. In 1851, a scientist, Rokitansky suggested the encrustation theory or thrombogenesis in which it is said that atherosclerosis began in the intima of arteries with the deposition of thrombus. This is followed by the organisation of the thrombus through infiltration of fibroblast, secondarily followed by deposition of lipid. The German pathologist, Rudolf Virchow postulated the insudation or inflammation theory in 1856, a different initiation of atherosclerosis. It was suggested that infiltration of fatty substances from the blood stream into the arterial wall leads to deposition of cholesterol which acts as an irritant, causing inflammation and the proliferation of cells. The cholesterol deposits act as irritant in the arterial intima, initiating inflammatory process as macrophages are incriminated as key role players in the phases of the disease. This theory was further supported by the work of N.N. Anitschkow in 1933 where he discovered that a disease resembling human atherosclerosis could be reproduced in rabbits with high serum cholesterol or LDL levels. He thus stated this occurrence may be as a result of defects in metabolism of lipids and lipids Schoenhagen, 2006).

The flow theory relates the circulation of blood in vessels to its effect on arterial wall. It stated that lesions occurred more often at curved, branching, or bifurcated sites, generally at regions of perturbed blood flow. Other hypotheses that arose from the flow theory include the stagnation point hypothesis by Fox and Hugh (1966), high wall shear stress hypothesis proposed by Fry (1968), low wall shear stress hypothesis by Caro et al. (1969), diminished lateral pressure hypothesis by Texon (1980) and the convection-diffusion hypothesis.

All the theories above were established based on three methods. Atherosclerotic plaques from autopsy findings from individuals of both sexes, various ages and race with different diseases which included hyperlipidaemia, diabetes and hypertension were considered. Epidemiological studies of factors which promote or prevent development of atherosclerosis, and finally experimental pathology which established the sequence of lesion development or regression were considered. None of these theories entirely explains the pathogenesis of atherosclerosis, but each has explained an aspect of this process. 


\subsection{Prevention and treatment of cardiovascular diseases}

The contributing factors to development of cardiovascular diseases are numerous as mentioned in the risk factors above. Lowering of plasma cholesterol levels is usually the first line of intervention for prevention and treatment of cardiovascular diseases. Dramatic successes have been recorded with cholesterol-lowering therapy which may suggest that maintenance of low cholesterol levels is sufficient to prevent development of atherosclerosis or reversing an established disease condition (Brunzell et al., 2008). Different approaches have been used for prevention and treatment of this condition, some are enumerated below.

\subsubsection{Role of High density lipoprotein-cholesterol (HDL-C)}

High density lipoprotein-cholesterol (HDL-C) is the smallest of the lipoprotein subfractions. It is however, the most complicated and diverse of the lipoproteins. It is the major lipoprotein which transports excess cholesterol from the plasma to the liver for excretion or utilization in the liver and other hormone producing regions of the body. Excess cholesterol is eliminated from the body via the liver, which secretes cholesterol in bile or converts it to bile salts (Toth, 2005; Tall, 2008). Also, its anti-inflammatory property protects LDL from oxidation and limits the concentrations of oxidized components, which may pose as atherogenic treats. HDL-C have been associated with reduced risk of cardiovascular events (Duffy and Rader, 2009; Khera et al., 2011). HDL-C plays a key role in the reverse transportation of cholesterol by accepting cholesterol from lipid-laden macrophages (Lehrke et al., 2007). In the study conducted by Khera et al. (2011), the ability of HDL to promote cholesterol efflux from macrophages was strongly and inversely associated with both subclinical atherosclerosis and obstructive coronary artery disease. It was also discovered that the associations persisted after adjustment for traditional cardiovascular risk factors, including the levels of HDL cholesterol and apolipoprotein A-I. HDL has several protein constituents which are exchangeable with other lipoproteins, and it acquires different apolipoproteins in the process of maturation such as apo AII, AIV, AV, CI, CII, CIII and E which results in generation of diverse HDL particles with various metabolic functions. In addition to being carrier proteins for the HDL particle, these proteins have protective roles which they play against cardiovascular diseases, such as by acting as anti-inflammatory regulators to limit the activity of pro-inflammatory cytokines.

Nascent HDL is synthesised and secreted by the liver and small intestine. It travels in the circulation where it gathers cholesterol to form mature HDL, which then returns the cholesterol to the liver via various pathways. Apolipoprotein A-I (ApoA-I) is the major protein component of high density lipoprotein (HDL) in plasma. The protein is encoded for by APOAI gene (Breslow et al., 1982, Arinami et al., 1990). Defects in this gene have been associated with HDL deficiencies (HUGO Gene Nomenclature Committee, 2011). This protein increases the efflux of cholesterol from tissue to liver where it is excreted. A few individuals were reported to produce a HDL ApoA-I protein variant called ApoA-I Milano, an abnormal and apparently more efficient apolipoprotein. It has low measured HDL-C levels yet very low rates of cardiovascular events even with high blood cholesterol values 
(Franceschini et al., 1981). Apo CI, CII and apo E also accumulate in the nascent HDL particle, which serves as a store for these apolipoproteins in circulation.

Phospholipids are transferred from macrophages by a specific transporter molecule known as ATP-binding cassette transport protein A1 (ABCA-1) into the core of the lipoprotein, and cholesterols are extracted from the cells by a transporter protein derived from macrophages in the sub-endothelial spaces of tissues; ABCG-1 transporter. The eventual maturation of the HDL particle is dependent on the lecithin: cholesterol acyltransferase (LCAT), an enzyme activated by apoAI, which catalyses the formation of cholesterol esters from cholesterol. Mobilization of free cholesterol and phospholipids from IDL and LDL continues until a matured, spherical HDL particle is formed. Endocytosis of the matured HDL into hepatocytes occurs and the cholesterol and cholesterol esters are transported via a facilitated transfer to distinct pools within the cell. The modified HDL particles are secreted back into circulation where they can further acquire cholesterol before they re-circulate to the liver. The complete reverse cholesterol transport occurs with the addition of apo E to the HDL particle which facilitates their uptake and catabolism.

\subsubsection{Lipoprotein Lipase as an anti-atherogenic agent}

Activation of lipoprotein lipase ( $\mathrm{LpL}$ ) activity has been reported to have anti-atherogenic activity. Lipoprotein lipase $(\mathrm{LpL})$ is a rate-limiting enzyme found on the surface of endothelial cells. It is polypeptide with 839 amino acids and an extracellular domain which binds to apo B100 and apo E. LpL catalyses the hydrolysis of the triacylglycerol (TAG) component of circulating chylomicrons and very low density lipoproteins (VLDL). The enzyme digests the TAG to fatty acids and monoglycerides. This provides non-esterified fatty acids and 2-monoacylglycerol which can be utilised immediately by cells for energy production or synthesis of other lipids. Unutilized fatty acids may be bound to circulating albumin and released slowly to meet future cellular requirements. Glycerol produced from LpL activity is transported back to the liver and kidneys, where it is converted to dihydroxyacetone phosphate in the alternative glycolytic pathway. The fatty acids from LpL activity in the muscle may diffuse into cells to be oxidized to two-carbon units or used to resynthesis TAG which are stored in adipose cells (Clee et al., 2000; Tsutsumi, 2003). Significant LpL activity occurs in muscle, adipose tissue and lactating mammary glands. Accumulation of VLDL remnants (IDL with apo B100 and apo E are converted to LDL with further loss of triacylglycerols. Both carrier proteins are necessary for recognition of IDL and LDL by the LDL receptors in the liver, after which they are taken up into hepatocytes by endocytosis and catabolized.

Research carried out over the past two decades have not only established a central role for $\mathrm{LpL}$ in the overall lipid metabolism and transport but have also identified additional, noncatalytic functions of the enzyme. Furthermore, abnormalities in LpL function have been found to be associated with a number of pathophysiological conditions, including atherosclerosis, chylomicronaemia, obesity, Alzheimer's disease, and dyslipidaemia associated with diabetes, insulin resistance, and infection (Mead et al., 2002). 


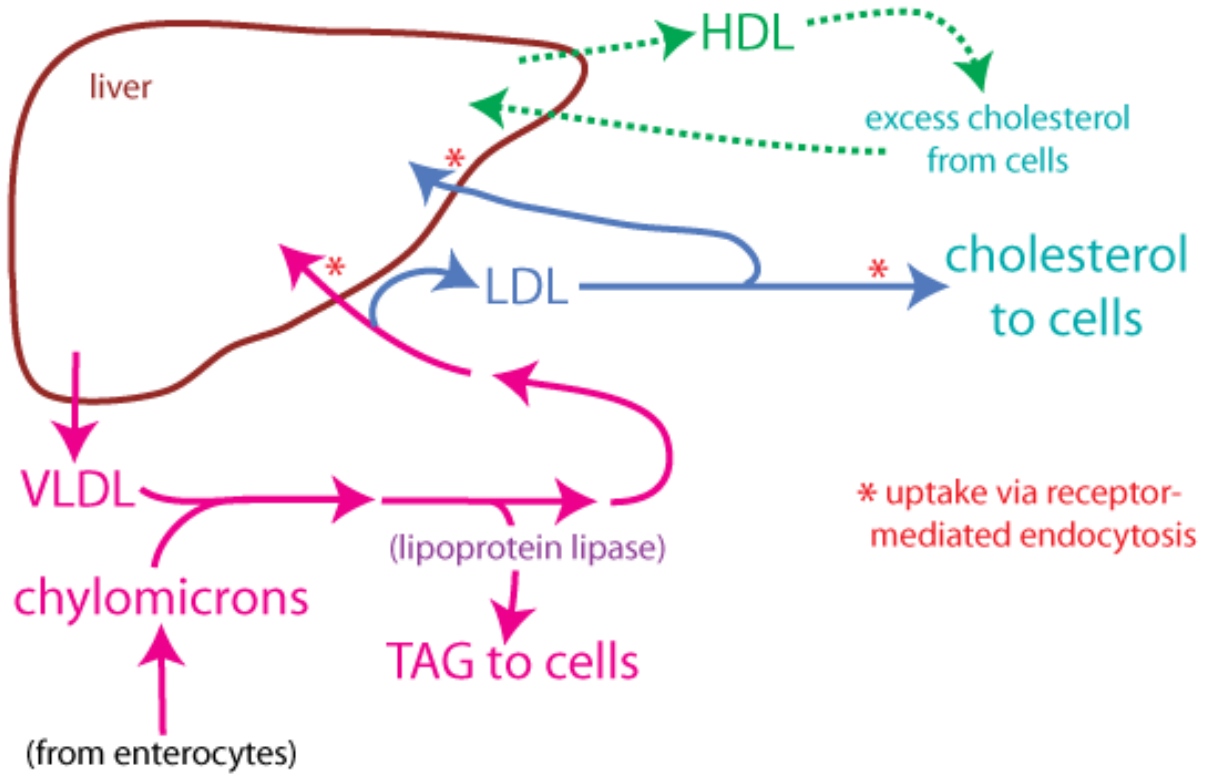

Figure 3. Summary of the fate of Lipoprotein sub-fractions (Adapted from http://courses.washington.edu/conj/bess/cholesterol/liver.html)

LpL encodes lipoprotein lipase, which is expressed in heart, muscle, and adipose tissue. LpL functions as a homodimer, and has the dual functions of triglyceride hydrolysis and ligand/bridging factor for receptor-mediated lipoprotein uptake. Through catalysis, VLDL is converted to IDL and then to LDL. Severe mutations that cause LpL deficiency result in type I hyperlipoproteinemia, while less extreme mutations in $\mathrm{LpL}$ are linked to many disorders of lipoprotein metabolism.

LpL isozymes are regulated differently depending on the tissue. For example, insulin is known to activate LpL in adipocytes and its placement in the capillary endothelium. By contrast, insulin has been shown to decrease expression of muscle LpL (Kiens et al., 1989). The form that is in adipocytes is activated by insulin, whereas that in muscle and myocardium is activated by glucagon and epinepherine. This helps to explain why during fasting, LpL activity increases in muscle tissue and decreases in adipose tissue. After feasting, the opposite occurs (Braun and Severson, 1992; Mead et al., 2002).

The concentration of LpL displayed on endothelial cell surface cannot be regulated by endothelial cells, as they neither synthesize nor degrade LpL. Instead, this regulation occurs by managing the flux of $\mathrm{LpL}$ arriving at the lipolytic site and being released into circulation attached to lipoproteins (Braun and Severson, 1992; Goldberg, 1996). The typical concentration of $\mathrm{LpL}$ in plasma is in the nanomolar range. Lipoprotein lipase deficiency leads to hypertriglyceridemia (elevated levels of triglycerides in the bloodstream) and 
decreased high density lipoprotein activity (Clee et al., 2000; Tsutsumi, 2003; Okubo et al., 2007). Diets high in refined carbohydrates have been shown to cause tissue-specific overexpression of LpL. This has been implicated in tissue-specific insulin resistance and consequent development of type 2 diabetes mellitus \& obesity.

\subsubsection{Influence of Hormones on plasma LDL-C and Lp(a) levels}

Several studies have reported conflicting reports on the effect of hormonal replacement therapy on plasma LDL-C and Lp(a) levels (Taskinen et al., 1996; Shlipak et al., 2000; Vigna et al., 2002). In a cohort study conducted by Danik et al. (2008), the effect of hormone replacement therapy $(\mathrm{HT})$ on $\mathrm{Lp}(\mathrm{a})$ and cardiovascular risk was investigated. It was reported that the relationship of high $\mathrm{Lp}(\mathrm{a})$ levels with increased cardiovascular disease is modified by hormonal therapy. These data suggest that the predictive utility of $L p(a)$ is markedly attenuated among women taking HT and may inform clinicians' interpretation of $\mathrm{Lp}(\mathrm{a})$ values in such patients. It was noteworthy that the effect of hormonal therapy was observed only in women with high LDL cholesterol levels, in agreement with previous studies suggesting an interaction between Lp(a) and LDL cholesterol (Berglung and Anuurad, 2008).

\section{Summary}

Elevated serum LDL-C and low levels of HDL-C are known as major and independent risk factors for CHD. Small, dense lipoprotein sub-fractions have been reported to have atherogenic potentials, with particular reference to Lipoprotein(a) $[\operatorname{Lp}(\mathrm{a})]$, a variant of low density lipoprotein (LDL). Other atherogenic sub-fractions of lipoproteins are VLDL, LDL, and IDL. These sub-fractions are characterized by the presence of apolipoprotein B-100, with an additional apolipoprotein known as apo(a) in the $\operatorname{Lp}(a)$ structure. Apo(a) is structurally and functionally similar to plasminogen and it accounts for virtually all the genetic variability in plasma Lp(a) levels. Variation of length within the kringle 4-encoding region of the apo(a) gene may account for a greater proportion of the inter-individual variation in plasma Lp(a) concentrations, with a strong genetic involvement inherited as a single autosomal dominant trait.

In the course of the pathogenesis of atherosclerosis, oxidized LDL is taken up by macrophages and into endothelial cells. This leads to formation of atherosclerotic plaques which precedes development of CHD. Oxidized LDL is antigenic and titres of autoantibodies against oxidized LDL in plasma can be used as indicator of a positive association with CHD. A positive association has also been established between plasma level of LDL, specifically oxidized LDL and other risk factors contributing to development of CHD. Such risk factors were identified as hypertriglyceridemia, reduced HDL-C levels, abdominal obesity and insulin resistance. Treatment of CHD can be achieved by lowering of plasma cholesterol levels which has been achieved by cholesterol-lowering therapy, suggesting that maintenance of low cholesterol levels may sufficiently prevent or reverse an established atherosclerosis. Increasing plasma levels of HDL-C has been reported to also be of benefit. 
HDL-C has anti-inflammatory activity which may prevent oxidation of LDL and it plays a key role in reverse transportation of cholesterol from lipid-laden macrophages.

The enzyme Lipoprotein lipase (LpL) may be useful in chemotherapy or prophylaxis of CHD. LpL has anti-atherogenic activity by its dual functions of triglyceride hydrolysis and ligand/brigding factor for receptor-mediated lipoprotein uptake. Activation of the enzyme is dependent on the tissue, resulting in variability of its activity. Hormonal replacement therapy may also be of benefit to patients with CHD and related diseases, but reported on current findings are conflicting.

\section{Author details}

Adebowale Saba and Olayinka Oridupa

University of Ibadan, Nigeria

\section{References}

Albers, J. J.; Adolphson J. L. \& Hazzard W. R. (1977). Radio-immunoassay of human plasma Lp(a) lipoprotein. J. Lipid Res. Vol 18, pp 331-338. ISSN 0022-2275

Arinami, T.; Hirano, T.; Kobayashi, K.; Yamanouchi, Y. \& Hamaguchi, H. (1990). Assignment of the apolipoprotein A-I gene to 11q23 based on RFLP in a case with a partial deletion of chromosome 11, del(11)(q23.3----qter). Hum. Genet. Vol. 85, No. 1, pp 39-40. PMID 1972696

Armstrong, V.W., Walli, A.K. \& Seidel, D. 1985. Isolation, characterization, and uptake in human fibroblasts of an apo (a)-free lipoprotein obtained on reduction of lipoprotein (a). J Lipid Res, Vol 26, pp 1314-1323. ISSN 0022-2275

Barter, P., Gotto, A.M., LaRosa, J.C., Maroni, J., Szarek, M., Grundy, M.S.S.M., Kastelein, J.J.P., Vera Bittner, V. \& Fruchart J. (2007). HDL Cholesterol, Very Low Levels of LDL Cholesterol, and Cardiovascular Events. N. Engl. J. Med. Vol 357, pp 1301-1310 (2007). /doi:10.1056/NEJMoa064278

Berg, K. \& Mohr, J. (1963). Genetics of the Lp system. Acta Genet. Vol. 13, pp 349-360. doi:10.1159/000151817

Berglund, L. \& Ramakrishnan, R. (2004). Lipoprotein(a): an elusive cardiovascular risk factor. Arterioscler. Thromb. Vasc. Biol. Vol. 24, No.12, pp 2219-26. doi:10.1161/ 01.ATV.0000144010.55563.63. PMID 15345512

Berglund, L. \& Anuurad, E. (2008). Role of lipoprotein(a) in cardiovascular diseases: Current and future perspectives. J Am Coll Cardiol, Vol 52, pp 132-134, doi:10.1016/j.jacc.2008.04.008.

Boerwinkle, E., Leffert, C.C., Lin, J., Lackner, C., Chiesa, G. \& Hobbs, H.H. (1992). Apolipoprotein (a) gene accounts fro greater than $90 \%$ of the variation in plasm lipoprotein (a) concentrations. J Clin Invest Vol 90, pp 52-60. 0021-9738/92/07/0052/09

Bowden, J.F., Pritchard, P.H., Hill, J.S. \& Frohlich, J.J. (1994). Lp(a) concentration and apo(a) isoform size. Relation to the presence of coronary artery disease in familial 
hypercholesterolemia. Arterioscler Thromb, Vol 14, pp 1561. doi: 10.1161/ 01.ATV.14.10.1561

Braun, J.E. \& Severson, D.L. (1992). Regulation of the synthesis, processing and translocation of lipoprotein lipase. Biochem J Vol. 287, No.2, (October, 1992) pp 337-47. PMC1133170

Breslow, J.L., Ross, D., McPherson, J., Williams, H., Kurnit, D., Nussbaum, A.L., Karathanasis, S.K. \& Zannis, V.I. (1982). Isolation and characterization of cDNA clones for human apolipoprotein A-I. Proc. Natl. Acad. Sci. U.S.A. Vol. 79, No. 22, pp 6861-5. doi:10.1073/pnas.79.22.6861. PMC 347233. PMID 6294659.

http://www.pubmedcentral.nih.gov/articlerender.fcgi?tool=pmcentrez\&artid=347233.

Brown, M.S. \& Goldstein, J.L. (2009). Cholesterol feedback: from Schenheimer's bottle to Scap's MELADL. J. Lipid Res. (April 2009), Vol. 50, S15-S27. doi:10.1194/jlr.R800054JLR200

Brunner, C., Lobentanz, E.M., Pethö-Schramm, A., Ernst, A., Kang, C., Dieplinger, H., Müller, H.J. \& Utermann, G. (1996). The number of identical kringle IV repeats in apolipoprotein(a) affects its processing and secretion by HepG2 cells. J. Biol. Chem. Vol. 271, No. 50, pp 32403-10. doi:10.1074/jbc.271.50.32403. PMID 8943305.

Brunzell, J.D., Davidson, M., Furberg, C.D., Goldberg, R.B., Howard, B.V., Stein, J.H. \& Witztum, J.L. (2008). Lipoprotein management in patients with cardiometabolic risk: Consensus conference report from the American Diabetes Association and the American College of Cardiology Foundation. J Am Coll Cardiol Vol. 51, pp 1512-1524. doi:10.1016/j.jacc.2008.02.034. Available from http://content.onlinejacc.org/cgi/content/full/51/15/1512

Carmena, R., Duriez, P. \& Fruchart, J.C. (2004). Atherogenic lipoprotein particles in atherosclerosis. Circulation Vol. 109, pp 2-7. doi: 10.1161/01.CIR.0000131511.50734.44. Available from http://circ.ahajournals.org/content/109/23_suppl_1/III-2

Chien, K.L., Hsu, H.C., Su, T.C., Sung, F.C., Chen, M.F. \& Lee, Y.T. (2008). Lipoprotein(a) and Cardiovascular Disease in Ethnic Chinese: The Chin-Shan Community Cardiovascular Cohort Study. Clinical Chemistry Vol. 54, pp 285-291, 2008. doi:10.1373/clinchem.2007.090969

Clee, S.M., Bissada, N., Miao, F., Miao, L., Marais, A.D., Henderson, H.E., Steures, P., McManus, J., McManus, MCManus, B., LeBoeuf, R.C., Kastelein, J.J.P. \& Hayden, M.R. (2000). Plasma and vessel wall lipoprotein lipase have different roles in atherosclerosis. J Lipid Res Vol. 41, pp 521-531. Available from

http://www.jlr.org/content/41/4/521.abstract

Danesh, J., Collins, R. \& Peto, R.. (2000). Lipoprotein(a) and Coronary Heart Disease: MetaAnalysis of Prospective Studies. Circulation. Vol. 102, pp 1082-1085 doi: 10.1161/01.CIR.102.10.1082

Danik, S., Rifai, N., Buring, J.E. \& Ridker P.M. (2008). Lipoprotein(a), Hormone Replacement Therapy, and Risk of Future Cardiovascular Events. J Am Coll Cardiol, Vol. 52, pp 124131, doi:10.1016/j.jacc.2008.04.009. ISSN 0735-1097/08.

Di Vizio, D., Solomon, K.R. \& Freeman, M.R. (2008). Cholesterol and cholesterol-rich membranes in prostate cancer: an update. Tumori Vol 5, pp 633-639. Available from 
http://www.tumorionline.it/allegati/00386_2008_05/fulltext/1\%20-

\%20Di\%20Vizio\%20\%28633-639\%29.pdf

Duffy, D. \& Rader, D.J. (2009). Update on strategies to increase HDL quantity and function. Nat Rev Cardiol; Vol. 6, pp 455-463. Available from www.ncbi.nlm.nih.gov

Eckel, R.H. (1997). Obesity and heart disease: a statement for healthcare professionals from the Nutrition Committee, American Heart Association. Circulation.Vol. 96, pp 3248 3250. doi: 10.1161/01.CIR.96.9.3248. Available from

http://circ.ahajournals.org/content/96/9/3248.full

Fahy, E., Subramaniam, S., Murphy, R., Nishijima, M., Raetz, C., Shimizu, T., Spener, F., Van Meer, G., Wakelam, M. \& Dennis, E.A. (2009). Update of the LIPID MAPS comprehensive classification system for lipids. Journal of Lipid Research Vol. 50, S9-S14. doi:10.1194/jlr.R800095-JLR200. PMID 19098281

Fredrickson, D.S., Lees, R.S. (1965). A system for phenotyping hyperlipoproteinaemia. Circulation Vol 31, No. 3, pp 321-327. Doi: 10.1161/01.CIR.31.3.321. PMID 14262568

Fletcher, G.F., Balady, G., Blair, S.N., Blumenthal, J., Caspersen, C., Chaitman, B., Epstein, S., Froelicher, E.S.S., Froelicher, V.F., Pina, I.L. \& Pollock, M.L. (1996). Statement on exercise: benefits and recommendations for physical activity programs for all Americans: a statement for health professionals by the Committee on Exercise and Cardiac Rehabilitation of the Councilon Clinical Cardiology, American Heart Association. Circulation, Vol. 94, pp 857- 862. doi: 10.1161/01.CIR.94.4.857. Available from http://circ.ahajournals.org/content/94/4/857.long

Franceschini, G., Sirtori, M., Gianfranceschi, G. \& Sirtori, C.R. (1981). Relation between the HDL apoproteins and AI isoproteins in subjects with the AIMilano abnormality. Metab. Clin. Exp. Vol 30, No. 5, pp 502-9. doi:10.1016/0026-0495(81)90188-8. PMID 6785551.

Garmendia, F. (2003). Advances in the knowledge and treatment of dyslipoproteinnemias. An. Fac. Med. Vol 64, No. 2, pp 101-106.

Garvey, W.T., Kwon, S., Zheng, D., Shaughnessy, S., Wallace, P., Hutto, A., Pugh, K., Jenkins, A.J., Klein, R.L. \& Liao Y. (2003). Effects of insulin resistance and type 2 diabetes on lipoprotein subclass particle size and concentration determined by nuclear magnetic resonance. Diabetes. Vol. 52, pp 453-462. Available from http://diabetes.diabetesjournals.org/content/52/2/453.full.pdf

Goldberg, I.J. (1996). Lipoprotein lipase and lipolysis: central roles in lipoprotein metabolism and atherogenesis. J Lipid Res Vol. 37, No. 4, pp 693-707. Available from

http://www.ncbi.nlm.nih.gov/pubmed/8732771

Guo, H.C., Michel, J.B., Blouquit, Y. \& Chapman, M. J. (1991). Lipoprotein(a) and apolipoprotein(a) in a new world monkey, the common marmoset (callithrix jacchus): Association of variable plasma lipoprotein(a) levels with a single apolipoprotein(a) isoform. Arterioscler. Thromb. Vol. 11, pp 1030-1041. doi:10.1161/01.ATV.11.4.1030 Available from http://atvb.ahajournals.org/content/11/4/1030

Grundy, S.M., Paternak, R., Greenland, P., Smith, S. \& Fuster, V. (1999). Assessment of cardiovascular risk by use of multiple-risk-factor assessment equations. Circulation Vol. 100, pp 1481-1492. doi: 10.1161/01.CIR.100.13.1481. Available from

http://circ.ahajournals.org/content/100/13/1481 
Holvoet, P., Mertens, A., Verhamme, P., Bogaerts, K., Beyens, G., Verhaeghe, R., Collen, D., Muls, E. \& Van de Werf, F. (2001). Circulating oxidized LDL is a useful marker for identifying patients with coronary artery disease. Arterioscler Thromb Vasc Biol,. Vol. 21, pp 844-848. doi: 10.1161/01.ATV.21.5.844. Available from http://atvb.ahajournals.org/content/21/5/844.full

HUGO Gene Nomenclature Committee (HGNC), (2011). APOA1 apolipoprotein A-I (Homo sapiens). Gene ID: 335, protein coding.

http://www.ncbi.nlm.nih.gov/sites/entrez?Db=gene\&Cmd=ShowDetailView\&TermToSe arch=335 Accessed on 9 November, 2011.

Hulthe, J. \& Fagerberg, B. (2002). Circulating oxidized LDL is associated with subclinical atherosclerosis development and inflammatory cytokines (AIR Study). Arterioscler Thromb Vasc Biol, Vol. 22, pp 1162-1167. doi: 10.1161/01.ATV.0000021150.63480.CD. Available from

http://atvb.ahajournals.org/content/22/7/1162.abstract?ijkey=80aaca3f2daac9fbc15623e16 18c678b0a8a2db5\&keytype2=tf_ipsecsha

Ikonen, E. (2008). Cellular cholesterol trafficking and compartmentalization. Nature Rev. Mol. Cell Biol. Vol. 9, pp 125-138. doi:10.1038/nrm2336

Iselius, L., Dahlen, G. H., De Faire, U. \& Lundman, T. (1981). Complex segregation analysis of the Lp(a)/pre-.13-lipoprotein trait. Clin. Genet.Vol. 20, pp 147-151. DOI: 10.1111/j.13990004.1981.tb01820.x. available from http://onlinelibrary.wiley.com/doi/10.1111/j.13990004.1981.tb01820.x/abstract

Kiens, B., Lithell, H., Mikines, K.J. \& Richter, E.A. (1989). Effects of insulin and exercise on muscle lipoprotein lipase activity in man and its relation to insulin action. J. Clin. Invest. Vol. 84, No. 4, pp 1124-9. 0021-9738/89/10/1124/06. Available from http://www.ncbi.nlm.nih.gov/pmc/articles/PMC329768/pdf/jcinvest00485-0080.pdf

Khera, A.V., Cuchel, M., de la Llera-Moya, M., Rodrigues, A., Burke, M.F., Jafri, K., French, B.C., Phillips, J.A., Mucksavage, M.L., Wilensky, R.L., Mohler, E.R., Rothblat, G.H. \& Rader, D.J. (2011). Cholesterol Efflux Capacity, High-Density Lipoprotein Function, and Atherosclerosis. N Engl J Med, Vol. 364, pp127-135. PMID 21226578. Available from www.ncbi.nlm.nih.gov/pubmed/21226578

Kraft, H.G., Lingenhel, A., Köchl, S., Hoppichler, F., Kronenberg, F., Abe, A., Mühlberger, V., Schönitzer, D. \& Utermann, G. (1996). Apolipoprotein(a) kringle IV repeat number predicts risk for coronary heart disease. Arterioscler Thromb Vasc Biol, Vol. 16, pp 713. PMID 8640397. Available from http://www.ncbi.nlm.nih.gov/pubmed/8640397

Lackner, C., E. Boerwinkle, Leffert, Rahmig, T. \& Hobbs, H. H. (1991). Molecular basis of sapolipoprotein(a) isoform size heterogeneity as revealed by pulsed-field gel electrophoresis. J. Clin. Invest., Vol. 87, pp 2077-2086. PMID 1645755. Available from http://www.ncbi.nlm.nih.gov/pubmed/1645755

Lamarche, B., Lemieux, I. \& Despres, J.P. (1999). The small, dense LDL phenotype and the risk of coronary heart disease: epidemiology, pathophysiology and therapeutic aspects. Diabetes Metab. Vol. 25, pp 199-211. PMID 10499189. Available from http://www.ncbi.nlm.nih.gov/pubmed/10499189?dopt=Abstract 
Leah, E. (2009). Cholesterol. Lipidomics Gateway. doi:10.1038/lipidmaps.2009.3. Available from http://www.lipidmaps.org/update/2009/090501/full/lipidmaps.2009.3.html.

Lehrke, M., Millington, S.C., Lefterova, M., Cumaranatunge, R.G., Szapary, P., Wilensky, R., Rader, D.J., Lazar, M.A. \& Reilly, M.P. (2007). CXCL16 is a marker of inflammation, atherosclerosis, and acute coronary syndromes in humans. J Am Coll Cardiol, Vol. 49, pp 442-449. doi:10.1016/j.jacc.2006.09.034. Available from

http://content.onlinejacc.org/cgi/content/full/49/4/442

Leinonen, J.S., Rantalaiho, V., Laippala, P., Wirta O, Pasternack A, Alho H, Jaakkola O, YlaHerttuala S, Koivula T \& Lehtimaki T. (1998). The level of autoantibodies against oxidized LDL is not associated with the presence of coronary heart disease or diabetic kidney disease in patients with non-insulindependent diabetes mellitus. Free Radic Res., Vol. 29, pp 137-141. PMID 9790515. Available from

http://www.ncbi.nlm.nih.gov/pubmed/9790515?dopt=Abstract

Loscalzo, J., Weinfeld, M., Fless, G.M. \& Scanu, A.M. (1990). Lipoprotein(a), fibrin binding, and plasminogen activation. Arteriosclerosis, Vol. 10, (March/April, 1990), pp 240-245. Available from atvb.ahajournals.org/content/10/2/240.full.pdf

McLean, J.W., Tomlinson, J.E., Kuang, W.J., Eaton, D.L., Chen, E.Y., Fless, G.M., Scanu, A.M. \& Lawn, R.M. (1987). cDNA sequence of human apolipoprotein(a) is homologous to plasminogen. Nature Vol. 300, No. 12, (November, 1987) pp 132-137.

Mead, J.R., Irvine, S.A. \& Ramji, D.P. (2002). Lipoprotein lipase: structure, function, regulation, and role in disease. J Mol Med, Vol. 80, No. 12, pp 753-69. PMID 12483461. Available from http://www.ncbi.nlm.nih.gov/pubmed/12483461

Muller-Roeber, B. \& Pical, C. (2002). Inositol Phospholipid Metabolism in Arabidopsis. Characterized and Putative Isoforms of Inositol Phospholipid Kinase and Phosphoinositide-Specific Phospholipase C. Plant Physiol., Vol. 130, No. 1, pp 22-46 doi: 10.1104/pp.004770

Okubo, M., Horinishi, A., Saito, M., Ebara, T., Endo, Y., Kaku, K., Murase, T. \& Eto, M.A. (2007). A novel complex deletion-insertion mutation mediated by Alu repetitive elements leads to lipoprotein lipase deficiency. Mol. Genet. Metab., Vol. 92, No. 3, pp 229-33. PMID 17706445. Available from

http://www.ncbi.nlm.nih.gov/pubmed/17706445

Palabrica, T.M., Liu, A.C., Aronovitz, M.J., Furie, B., Lawn, R.M. \& Furie, B.C. (1995). Antifibrinolytic activity of apolipoprotein(a) in vivo: human apolipoprotein(a) transgenic mice are resistant to tissue plasminogen activator-mediated thrombolysis. Nat Med, Vol. 1, pp 256. Available from http://www.nature.com/naturemedicine

Patrick, L. \& Uzick, M. (2001). Cardiovascular disease: C-reactive protein abd the inflammatory disease paradigm: HMG-CoA reductase inhibitors, alpha-tocopherol, red yeast rice and olive oil polyphenols. A review of the literature. Altern Med Rev Vol. 6, No. 3, pp 248-271. Available from http://www.thorne.com/altmedrev/.fulltext/6/3/248.pdf

Pearson, A., Budin, M. \& Brocks, J.J. (2003). Phylogenetic and biochemical evidence for sterol synthesis in the bacterium Gemmata obscuriglobus. Proc. Natl. Acad. Sci. U.S.A. Vol. 100, No. 26, pp 15352-7. doi:10.1073/pnas.2536559100. PMC 307571. PMID 14660793. 
Rader, D.J., Cain, W., Zech, L.A., Usher, D. \& Brewer, H.B. (1993). Variation in lipoprotein(a) concentrations among individuals with the same apolipoprotein (a) isoform is determined by the rate of lipoprotein(a) production. J. Clin. Invest. Vol. 91, No. 2, pp 443-7. doi:10.1172/JCI116221. PMC 287951. PMID 8432853

Sandholzer, C., Hallman, D.M., Saha, N., Sigurdsson, G., Lackner, C., Császár, A., Boerwinkle, E. \& Utermann, G. (1991). Effects of the apolipoprotein(a) size polymorphism on the lipoprotein(a) concentration in 7 ethnic groups. Hum. Genet. Vol. 86, No. 6, pp 607-14. doi:10.1007/BF00201550. PMID 2026424.

Schreiner, P.J., Morrisett, J.D., Sharrett, A.R., Patsch, W., Tyroler, H.A., Wu, K. \& Heiss, G. (1993). Lipoprotein(a) as a risk factor for preclinical atherosclerosis. Arterioscler. Thromb., Vol. 13, No. 6, pp 826-33. doi:10.1161/01.ATV.13.6.826. PMID 8499402

Schoenhagen, M. (2006). Current developments in atherosclerosis research. Misra Schoenhagen (editor). Published by Nova Science Inc., New York. ISBN 1-59454-493-X. Available from http://www.novapublishers.com

Sherer, Y., Tenenbaum, A., Praprotnik, S., Shemesh J, Blank M, Fisman EZ, Harats D, George J, Levy Y, Peter JB, Motro M, Shoenfield Y. (2001). Coronary artery disease but not coronary calcification is associated with elevated levels of cardiolipin, beta-2glycoprotein-I, and oxidized LDL antibodies. Cardiology, Vol. 95, pp 20-24. PMID 11385187. Available from

http://www.ncbi.nlm.nih.gov/pubmed/11385187?dopt=Abstract

Shlipak, M.G., Simon, J.A., Vittinghoff, E., Lin, F., Barrett-Connor, E., Knopp, R.H., Levy, R.I. \& Hulley, S.B. (2000). Estrogen and progestin, lipoprotein(a), and the risk of recurrent coronary heart disease events after menopause. JAMA, Vol. 283, pp 1845-1852. URL: http://jama.ama-assn.org/cgi/content/abstract/283/14/1845

Soedamah-Muthu, S.S., Chang, Y.F., Otvos, J., Evans, R.W. \& Orchard, T.J. (2003). Lipoprotein subclass measurements by nuclear magnetic resonance spectroscopy improve the prediction of coronary artery disease in type 1 diabetes: a prospective report from the Pittsburgh Epidemiology of Diabetes Complications Study. Diabetologia, Vol. 46, pp 674-682. PMID 12743701. Available from http://www.ncbi.nlm.nih.gov/pubmed/12743701?dopt=Abstract

Sotiriou, S.N., Orlova, V.V., Al-Fakhri, N., Ihanus, E., Economopoulou, M., Isermann, B., Bdeir, K., Nawroth, P.P., Preissner, K.T., Gahmberg, C.G., Koschinsky, M.L. \& Chavakis, T. (2006). Lipoprotein(a) in atherosclerotic plaques recruits inflammatory cells through interaction with Mac-1 integrin". FASEB J. Vol. 20, No 3, pp 559-61. PMID 16403785. Available from http://www.ncbi.nlm.nih.gov/pubmed/16403785

Steinbrecher, U.P., Parthasarathy, S., Leake, D.S., Witztum, J.L. \& Steinberg, D. (1984). Modification of lowdensity lipoprotein by endothelial cells involves lipid peroxidation and degradation of low density lipoprotein phospholipids. Proc Natl Acad Sci U S A., Vol. 81, pp 3883-3887. Available from http://www.pnas.org/content/81/12/3883.abstract?ijkey=fea45b830edf328270f68e98a3cc0 3d2bb008eff\&keytype2=tf_ipsecsha 
Tall, A.R. (2008). Cholesterol efflux pathways and other potential mechanisms involved in the athero-protective effect of high density lipoproteins. J Intern Med, Vol. 263, No. 3, pp 256-273. ISSN 0954-6820

Taskinen, M.R., Puolakka, J., Pyorala, T., Luotola, H., Bjorn, M., Kaariainen, J., Lahdenpera, S. \& Ehnholm, C. (1996). Hormone replacement therapy lowers plasma Lp(a) concentrations. Comparison of cyclic transdermal and continuous estrogen-progestin regimens. Arterioscler Thromb Vasc Biol, Vol. 16, pp 1215-1221. doi: 10.1161/ 01.ATV.16.10.1215. Available from http://atvb.ahajournals.org/content/16/10/1215.full

Toshima, S., Hasegawa, A., Kurabayashi, M., Itabe, H., Takano, T., Sugano, J., Shimamura, K., Kimura, J., Michishita, I., Suzuki, T. \& Nagai, R. (2000). Circulating oxidized low density lipoprotein levels: a biochemical risk marker for coronary heart disease. Arterioscler Thromb Vasc Biol., Vol. 20, pp 2243-2247. doi: 10.1161/01.ATV.20.10.2243. Available from http://atvb.ahajournals.org/content/20/10/2243.abstract?ijkey=4a5cafa55c6ce067f39ca5eb 803d7801adb5f339\&keytype2=tf_ipsecsha

Toth, P. (2005). The good cholesterol High-Density Lipoprotein. Circulation, Vol. 111, No. 5, pp e89-e91. Available from http://circ.ahajournals.org/cgi/content/full/111/5/e89.

Tsutsumi, K. (2003). Lipoprotein lipase and atherosclerosis. Curr Vasc Pharm, Vol. 1, pp 1117. ISSN 1570-1611/03

Utermann, G. (1989). The mysteries of lipoprotein(a). Science, Vol. 246, No. 4932, pp 904-10. Available from www.sciencemag.org

Vakkilainen, J., Steiner, G., Ansquer, J.C., Aubin, F., Rattier, S., Foucher, C., Hamsten, A \&, Taskinen, M. (2003). Relationships between low-density lipoprotein particle size, plasma lipoproteins, and progression of coronary artery disease: the Diabetes Atherosclerosis Intervention Study (DAIS). Circulation., Vol. 107, pp 1733-1737. doi: 10.1161/01.CIR.0000057982.50167.6E. Available from

http://circ.ahajournals.org/content/107/13/1733.abstract?ijkey=401352270488f9ca9f3caafa f43179b7a352181c\&keytype2=tf_ipsecsha

Vance, D.E. \& Vance, J.E. (2002). Biochemistry of lipids, lipoproteins and membranes. Elsevier, Amsterdam. ISBN 978-0-444-53219-0.

Vigna, G.B., Donega, P., Zanca, R., Barban, A., Passaro, A., Pansini, F., Bonaccorsi, G., Mollica, G. \& Fellin, R. (2002). Simvastatin, transdermal patch, and oral estrogenprogestogen preparation in early-postmenopausal hypercholesterolemic women: a randomized, placebo-controlled clinical trial Metabolism, Vol. 51, pp 1463-1470.

Wang, X., Briggs, M. R., Hua, X., Yokoyama, C., Goldstein, J. L. \& Brown. M. S. (1993). Nuclear protein that binds sterol regulatory element of LDL receptor promoter: II. Purification and characterization. J. Biol. Chem. Vol. 268, pp 14497-14504.

White, A.L., Rainwater, D.L., Hixson, J.E., Estlack, L.E. \& Lanford, R.E. (1994). Intracellular processing of apo(a) in primary baboon hepatocytes. Chem. Phys. Lipids, Vol. 67-68, pp 123-33. doi:10.1016/0009-3084(94)90131-7. PMID 8187206.

Wilson, P.W., D’Agostino, R.B., Levy, D., Belanger, A.M., Silbershatz, H. \& Kannel, W.B. (1998). Prediction of coronary heart disease using risk factor categories. Circulation., Vol. 97, pp 1837-1847. PMID 9603539. Available from http://www.ncbi.nlm.nih.gov/pubmed/9603539 
Young, I.S. \& McEneny, J. (2001). Lipoprotein oxidation and atherosclerosis. Biochem Soc Trans 29 (2): 358-362. PMID 11356183. Available from http://www.ncbi.nlm.nih.gov/pubmed/11356183

Yokoyama, C., Wang, X., Briggs, M. R., Admon, A. , Wu, J., Hua, X., Goldstein, J. L. \& Brown, M. S. (1993). SREBP-1, a basic helix-loop-helix leucine zipper protein that controls transcription of the LDL receptor gene. Cell. Vol. 75, pp 187-197. PMID 8402897. Available from http://www.ncbi.nlm.nih.gov/pubmed/8402897

Zenker, G., Koltringer, P., Bone, G., Niederkorn, K., Pfeiffer, K. \& Jurgens, G. (1986). Lipoprotein(a) as a strong indicator for cerebrovascular disease. Stroke, Vol. 17, pp 942945. doi: 10.1161/01.STR.17.5.942. Available from http://stroke.ahajournals.org/content/17/5/942.

Zioncheck, T.F., Powell, L.M., Rice, G.C., Eaton, D.L. \& Lawn, R.M. (1991). Interaction of recombinant apolipoprotein(a) and lipoprotein(a) with macrophages. J Clin Invest, Vol. 87, pp 767. 0021-9738/91/03/0767/05 